\title{
CUKOR- ÉS SAV ÖSSZETEVÖK VIZSGÁLATA KÜLÖNBÖZŐ SZILVAFAJTÁKBAN
}

\section{ANALYSIS OF SUGAR AND ACID COMPOUNDS IN DIFFERENT PLUM VARIETIES}

\author{
Kajtár-Czinege Anikó ${ }^{1}$, Dr. Kapcsándi Viktória ${ }^{2}$, Székelyhidi Rita², Dr. Németh-Torkos Anett \\ 2,Hanczné Dr. Lakatos Erika ${ }^{2}$ \\ ${ }^{1}$ Kertészeti Tanszék, Kertészeti és Vidékfejlesztési Kar, Neumann János Egyetem, Magyarország \\ Élelmiszertudományi Tanszék, Élelmiszertudományi Kar, Széchenyi István Egyetem, Magyarország \\ https://doi.org/10.47833/2020.2.AGR.010
}

\section{Kulcsszavak: \\ szilva \\ beltartalmi értékek \\ cukorösszetevők \\ savösszetevők}

\section{Keywords:}

plum

content value

sugar compounds

acid component

\section{Cikktörténet:}

Beérkezett 2019. október 10.

Átdolgozva 2020. március 10.

Elfogadva 2020. március 20.

\begin{abstract}
Összefoglalás
A szilva az egészséges étrend elengedhetetlen alkotóeleme lenne. Az emésztő-szervrendszer megbetegedésének megelözésében fontos szerepet játszhatna, ha a korunk embere megbecsülné ezt a méltatlanul elhanyagolt gyümölcsöt. A jótékony hatását elsősorban a rost-tartalmának köszönheti, de fontos szerepet játszanak a cukrok és savak is. Cukrokban igen gazdag, összetett vizsgálatunknak egyik megfigyelési szempontja éppen a cukortartalom-változás illetve emellett a savtartalom változása, miként a friss gyümölcsböl aszalvány vagy éppen lekvár készül.

Cikkünkben bemutatásra kerülnek az egyes cukor-összetevők, melyek a szilva friss gyümölcsében találhatók. Valamint a belöle készült termékek cukortartalmára is kiterjedt a vizsgálatunk. A cukrok mellett a sav-összetevőket is mértük, mind a friss gyümölcsben, mind annak változását a termékekben. Ezek eredményeit kívánjuk bemutatni.
\end{abstract}

\section{Abstract}

Plums would be an essential component of a healthy diet. It would be important for a person of our age to appreciate this undeservedly neglected fruit to help prevent digestive tract disease. Its beneficial effects are mainly due to its fiber content, but sugars and acids also play an important role. One of the observational aspects of our complex study, rich in sugars, is the change in the sugar content and the change in the acid content, as in the case of fresh fruits made from dried fruit or jam.

This article describes the individual sugar components found in the fresh fruit of the plum. The sugar content of the products made from it was also examined. In addition to sugars, we measured the acid components, both in the fresh fruit and in its changes in the products. We would like to present the results of these.

\footnotetext{
* Kapcsolattartó szerző. Tel.: +36 76/517- 693

E-mail cím: czinege.aniko@kvk.uni-neumann.hu
} 


\section{Bevezetés}

A gyümölcsök a bennük lévő vitaminok, ásványi anyagok, antioxidánsok miatt rendkívül egészséges csemegének, élelemnek számítanak. Ráadásul a belölük készült termékek kisebbnagyobb mértékben megőrzik egészségvédő tulajdonságukat, a bioaktív anyagok főzés hatására elbomolhatnak vagy éppen aszalás következtében koncentrálódhatnak. A szilva gyümölcse igen gazdag a cukrokban és a savösszetevői is jelentősek, melynek köszönhetően javítja, élénkíti az emberi anyagcsere folyamatait, így az egészségre gyakorolt hatása kiemelkedő. A különböző cukorösszetevők, savak, polifenol tartalom nem csak a friss szilva gyümölcsére jellemző, hanem a belöle készült termékek is megőrzik ezen összetevőket, így a különböző szilvatermékek is hatékonyak az egészség megőrzésében.

\section{Irodalmi áttekintés}

A gyümölcsök, így a szilva táplálkozásbiológiai értékét az alkotó vegyületeinek, elemeinek összetétele és minősége határozza meg. A gyümölcsfogyasztás egészségvédő és megőrző hatása az alkotó vegyületek összetett, kumulatív hatásának köszönhető [5]. A szilva igen gazdag szerves savakban és szénhidrátokban (cukrokban) [1].

Irodalmai adatok szerint a szilvában magas $(4,1 \mathrm{~g} / 100 \mathrm{~g})$ a szacharózt és $(3,7 \mathrm{~g} / 100 \mathrm{~g})$ a glükózt kevesebb, míg a fruktózt csupán kis $(1,6 \mathrm{~g} / 100 \mathrm{~g})$ mennyiségben tartalmazza [6].

Szerves savakban is gazdag. A szerves sav tartalom eredményezi az emberi szervezet anyagcsere fokozó hatását.

A feldolgozást követően a cukrok jelentős része és a savak egy része megmarad a szilva termékekben. Az aszalt szilva és a szilvalekvár különösen jótékonyan hat az emésztésre, e miatt évszázadokon keresztül gyógyszerként értékesítették. Hieronymus Füszerkönyve (1551) a fehérboros fözött aszalt szilvát ajánlja emésztési bajokra.

\section{Szerves savak}

A gyümölcsökben legföképpen almasav és citromsav található, de e mellett a Krebs-ciklusból származó savak is jelentősek, mint például a borostyánkősav, alfa-ketogluténsav, oxálecetsav, fumársav, piroszőlősav. Továbbá egyéb savak is jelen lehetnek a gyümölcsben, mint például: sikimisav, kinosav, kávésav. [4]

Savak közül a szilva 1,32 g/100 g almasavat; $0,26 \mathrm{~g} / 100 \mathrm{~g}$ borkösavat; $0,16 \mathrm{~g} / 100 \mathrm{~g}$ borostyánkősavat és $0,11 \mathrm{~g} / 100 \mathrm{~g}$ citromsavat tartalmaz [8]

\section{Szénhidrátok-cukrok}

Bíró és Lindner [1] kimutatta, hogy gyümölcsök oldható szárazanyag-tartalom jelentös részét cukrok és zsírok alkotják. Három-féle cukor- féleséget mutattak ki, így a fruktózt $(4-4,3 \mathrm{~g} / 100 \mathrm{~g})$; glükózt (3,2-5,1 g/100g); és a szacharózt (3,8-4,6 g/100 g).

A szilvában a szacharóz a fö cukoralkotó [4]. Ezen kívül más cukrok is jelen vannak, mint például: fruktóz, $\alpha$ - glükóz, $\beta$-glükóz, szorbit. [11]

Bíró- Lindner [2] vizsgálatai alapján a szilva 4,1 g/100 g szacharózt; 3,7 g/100 g glükózt; és $1,6 \mathrm{~g} / 100 \mathrm{~g}$ fruktózt tartalmaz.

Tóth [9] vizsgálatai kimutatták, hogy minél későbbi érésü a szilvafajta általában nagyobb a száraz-anyagtartalom és az invertcukor tartalma valamint alacsonyabb a savtartalma.

\section{A szilva táplálkozás-élettani jelentősége}

A szilva gyümölcse a múltban igen jelentős gyógyászati terméknek számított, mivel a Besztercei szilvát laxatív hatása miatt fogyasztották. Ez a tulajdonsága a magas rosttartalmának és borkősav tartalmának köszönhetö.

A szilva mind szárazanyag-, mind cukortartalma 20-40\%-kal felülmúlja az almáét vagy az őszibarackét, savtartalma pedig a körtéét és az őszibarackét. Bíró és Lindner [1] vizsgálatainak eredményei felhívják a figyelmet arra, hogy a fajon belül a fajták között is igen eltérő a beltartalmi összetevők alakulása.

A gyümölcs beltartalmi értékeinek, összetevőinek alakulását számos tényező befolyásolja, mint az évjárathatás, időjárás, termőhely, alany, fajta, művelési rendszer, termesztés technológia, érettségi állapot. Így a sokévi átlageredmények adnak tájékoztatást a gyümölcs beltartalmi értékeire vonatkozólag.

\section{Szilva aszalvány}


Napjainkban a szilvaaszalás a reneszánszát éli, de nem csak szilvából készülnek ilyen jellegü csemegék. Aszaláskor a romlást okozó mikroorganizmusok müködéséhez szükséges vizet vonják el a gyümölcsböl, így tartósítva azt.

Hazai szilvafajták aszalási alkalmasságát végezte el a '50-'60-as években Tóth Elek. A különböző szilvafajtákból készült aszalvány minősége, beltartalma is más és más volt, fajtáktól függően, a bennük lévő eltérő víztartalom miatt. Ezen okból az aszalási technológia is eltérő lehet fajtától függően. Tóth [10] azt tapasztalta, hogy hazai körülmények között a 'Besztercei muskotály', 'Olasz kék', 'Paczelt szilvája', és az 'Ageni' bizonyult kiváló minőségünek. Ezen vizsgálatok csak organoleptikus vagyis érzékszervi vizsgálatokon alapult, beltartalmi összetevőkre adatok nincsenek.

Simon [7] vizsgálatai szerint a 'Révfülöpi' szilvafajta kiváló aszalványt adott, de jó eredményeket mutatott a 'Čačanska rodna', a 'Beszrecei', és a 'Blufre' fajták is.

\section{Szilvalekvár}

A különböző cukorösszetevők, savak, polifenol tartalom nem csak a friss szilva gyümölcsére jellemző, hanem a belöle készült termékek is megőrzik ezen alkotókat, így a különböző szilvatermékek is hatékonyak az egészség megörzésében. Mivel az igazi szilvalekvár csak szilvát tartalmaz, hozzáadott anyagokat nem, így csupán a szilva összetevők fejtik ki hatásukat az emberi szervezetre, de hosszadalmas fözés hatására elbomolhatnak az értékes anyagok.

A szilvafajták tulajdonságai, eltérő arányú gyümölcsalkotói, összetevői hatással vannak a belőle készült kész termékek minőségére, élvezeti értékére, egészségre gyakorolt hatására. [3]

\section{Anyag és módszer}

5 szilvafajtánál végeztünk méréseket a cukor és sav összetevőkre vonatkozóan, ezek a szerb 'Čačanska lepotica'; a német 'Katinka'; 'Jojo'; 'Topper'; és 'Toptaste' fajták.

A szerves savak közül citromsavat, almasavat, borkősavat és borostyánkősavat mértünk.

Cukrok közül szacharóz, glükóz és fruktóz mennyiségét vizsgáltuk a szilvafajtákban, továbbá polifenol tartalomra is kiterjedtek méréseink. Ezeket a méréseket friss szilva gyümölcsökben, és a belöle készült aszalványban és lekvárban is elvégeztük.

\section{Minta előkészítés, mérés menete:}

Vizsgálatainkhoz a szilvát nyers állapotban, lekvárként, ill. aszalványként használtuk fel.

A friss gyümölcsfogyasztásra alkalmatlan részeit mosás után eltávolítottuk majd a magozáskor már feltárt gyümölcshúst a kézi konyhai aprítóval tovább aprítottuk, ügyelve arra, hogy a gyümölcshéj és a gyümölcshús aránya hasonló legyen, mérete pedig $<1 \mathrm{~mm}$.

A lekvárhoz a gyümölcsöt hasonlóképpen készítettük elő, a magozott szilva-feleket viszont nem aprítottuk tovább. Egy elektromos tüzhelyen a szilvalekvárok egyéb adalékanyagok hozzáadása nélkül folytonos keverés mellett kb. 3 óra alatt készültek el, ügyeltünk arra, hogy minden fözés állaga megegyezzen. Az aszalt gyümölcs a magozott szilva felekből aszaló gépben készült $55^{\circ} \mathrm{C}$-on 36 óra alatt.

A savösszetevők méréséhez a vizes extrakció menete: bemért tömegek: szilva $1 \mathrm{~g}$, aszalvány és lekvár $0,1 \mathrm{~g}+5 \mathrm{ml}$ vízkevertetés mágneses keverővel $60 \mathrm{~min}$-ig, majd centrifugálás $5500 \mathrm{~g} 30$ min-ig; ezután az extraktumból 5x hígítás végeztünk mérölombikba, majd jelre töltöttük $0,1 \% \mathrm{H}_{2} \mathrm{SO}_{4}$ oldattal. Ezt követöen $1,5 \mathrm{ml}$ eppendorf csőben centrifugáltunk $24500 \mathrm{~g} 20 \mathrm{~min}$-ig. Ebböl $1 \mathrm{ml}$ szürtünk le egy $1,8 \mathrm{ml}$-es fiolába. Végül a felsorolt vizsgálni kívánt szerves savakat ionkizárásos folyadékkromatográfiával végeztük.

Cukor összetevők méréséhez a vizes extrakció menete: bemértünk friss szilvából $1 \mathrm{~g}$-t; aszalványból és lekvárból $0,1 \mathrm{~g}$-t hozzáadtunk $5 \mathrm{ml}$ vizet és mágneses keverővel $60 \mathrm{~min}$-ig kevertettük. Majd Centrifugáltuk: $5500 \mathrm{~g} 30 \mathrm{~min}$-ig. Ezt követöen az extraktumból 5x hígítást végeztünk mérölombikba, majd jelre töltöttük eluenssel $\left(100 \% \mathrm{H}_{2} \mathrm{O}\right)$. Ezután $1,5 \mathrm{ml}$ eppendorf csőbe centrifugáltuk $24500 \mathrm{~g} 20$ min-ig. Végül $1 \mathrm{ml}$ szürése 1,8 ml-es fiolába.

A felsorolt vizsgálni kívánt cukrok elválasztását ionkizárásos oszlopon végeztük fordított fázisú folyadékkromatográfiával. 


\section{Eredmények}

\subsection{Szerves savak a vizsgált szilvafajtákban}

A vizsgálat során citromsavat és borkősavat nem mutattak ki a mintákból, ezért nem szerepelnek a táblázatban.

A friss gyümölcshöz képest a lekvár almasav tartalma nőtt valamennyi mintánál kivéve a 'Topper' fajtát (1. táblázat). Az aszalványok esetében jelentősen, 5-6 szoros növekedést figyelhettünk meg ugyanezen összetevőnél, a 'Topper' fajta aszálványnál is növekedést mutatott, de csekély $(1,5 \mathrm{mg} / \mathrm{g})$ volt ez a növekedés.

A borostyánkősav esetében a friss gyümölcshöz képest a lekvárban egy kisebb jellegü csökkenést tapasztaltunk, vagyis hő hatására egy része elbomlott. Az aszalványban viszont 3-10 szoros növekedés mutatkozott. A 10-szeres növekedés a 'Toptaste' fajtánál figyelhető meg. A fajták közül a 'Čačanska lepotica' friss gyümölcse mutatta a legmagasabb almasav tartalmat (15,8 $\mathrm{mg} / \mathrm{g})$, míg igen alacsony (2,4 mg/g) volt a 'Topper' almasav összetevője.

A friss 'Čačanska lepotica' fajta gyümölcsénél kimagasló almasav mellett a borostyánkősav alacsony értékkel $(4,1 \mathrm{mg} / \mathrm{g})$ jellemezhetö. A 'Katinka' és a 'Topper'; fajtáknál az almasav és a borostyánkősav azonos (1:1) arányban oszlott meg. A 'Topper' fajta mutatta a legalacsonyabb $(2,5$ $\mathrm{mg} / \mathrm{g})$ borostyánkősav szintet, míg a 'Katinka' a legmagasabb $(8,4 \mathrm{mg} / \mathrm{g})$ értéket.

Az aszalványok magasabb értékkel jellemezhetőek, ezek közül is kiemelhető 'Čačanska lepotica' aszalványa magas $(75,7 \mathrm{mg} / \mathrm{g})$ almasav tartalommal. Borkősavtartalom szempontjából pedig a 'Toptaste' értéke $(45,6 \mathrm{mg} / \mathrm{g})$ magas.

1. táblázat: Szerves savak alakulása a vizsgált szilvafajtákban

\begin{tabular}{|c|l|l|l|l|l|}
\hline & & Almasav (mg/g) & RSD\% & $\begin{array}{c}\text { Borostyánkösav } \\
(\mathbf{m g} / \mathbf{g})\end{array}$ & RSD\% \\
\hline 'Katinka' & Nyers & $8,3 \pm 0,4$ & 5 & $8,4 \pm 0,5$ & 5 \\
\hline & Lekvár & $10,4 \pm 1,0$ & 8 & $6,17 \pm 0,1$ & 1 \\
\hline & Aszalvány & $39,5 \pm 4,5$ & 10 & $31,3 \pm 1,3$ & 5 \\
\hline $\begin{array}{c}\text { 'Čačanska } \\
\text { lepotica' }\end{array}$ & Nyers & $15,8 \pm 0,8$ & 5 & $4,1 \pm 0,2$ & 5 \\
\hline & Lekvár & $23,3 \pm 2,8$ & 10 & $3,54 \pm 0,1$ & 1 \\
\hline & Aszalvány & $75,7 \pm 7,1$ & 8 & $17,7 \pm 1,7$ & 8 \\
\hline 'Toptaste' & Nyers & $5,5 \pm 0,4$ & 7 & $4,4 \pm 0,1$ & 1 \\
\hline & Lekvár & $7,9 \pm 0,6$ & 7 & $2,6 \pm 0,3$ & 1 \\
\hline & Aszalvány & $43,7 \pm 5,6$ & 10 & $45,6 \pm 0,1$ & 1 \\
\hline 'Jojo' & Nyers & $8,3 \pm 0,6$ & 6 & $3 \pm 0,2$ & 1 \\
\hline & Lekvár & $20,5 \pm 2,1$ & 9 & $1,0 \pm 0,1$ & 1 \\
\hline & Aszalvány & $41,6 \pm 3,4$ & 7 & $20,1 \pm 1,4$ & 1 \\
\hline 'Topper' & Nyers & $2,4 \pm 0,2$ & 7 & $2,5 \pm 0,1$ & 1 \\
\hline & Lekvár & $1,6 \pm 0,1$ & 8 & $0,22 \pm 0,002$ & 1 \\
\hline & Aszalvány & $3,9 \pm 0,3$ & 8 & $10,2 \pm 0,5$ & 5 \\
\hline
\end{tabular}

\subsection{Cukrok a vizsgált szilvafajtákban}

A cukrok esetében (2. táblázat)'Toptaste' szilvafajta friss gyümölcse mutatta a legmagasabb (75,5 mg/g) szacharóz értéket és a legmagasabb fruktóz értéket $(31,4 \mathrm{mg} / \mathrm{g})$.

A glükóz esetében viszont a 'Jojo' friss minta mutatott kimagasló $(40,1 \mathrm{mg} / \mathrm{g})$ értéket. Igen alacsony cukor összetevők jellemzik a 'Topper' friss gyümölcsöt. A lekvárok meglepően alacsony cukorösszetevőket mutatnak. Ellenben az aszalványok a várakozásnak megfelelően, igen magas szintü cukortartalommal jellemezhetök, közülük is a glükóz és a fruktóz. Ebböl a szempontból 
kiemelhető a 'Jojo' aszalványa (296,2 mg/g) glükóz összetevő esetén. A fruktóznál a 'Čačanska lepotica' értéke kimagasló $(216,1 \mathrm{mg} / \mathrm{g})$.

2. táblázat: Cukrok alakulása a vizsgált szilvafajtákban

\begin{tabular}{|c|c|c|c|c|c|c|c|}
\hline & & $\begin{array}{c}\text { Szacharóz } \\
\text { (mg/g) }\end{array}$ & $R S D \%$ & $\begin{array}{c}\text { Glükóz } \\
\text { mg/g }\end{array}$ & $R S D \%$ & $\begin{array}{c}\text { Fruktóz } \\
\text { (mg/g) }\end{array}$ & $R S D \%$ \\
\hline \multirow[t]{3}{*}{ 'Katinka' } & Nyers & $52,2 \pm 3,9$ & 7 & $30,7 \pm 1,8$ & 5 & $14,4 \pm 0,4$ & 3 \\
\hline & Lekvár & n.a & - & $14,3 \pm 0,5$ & 2 & $4,8 \pm 0,1$ & 1 \\
\hline & Aszalvány & $12,6 \pm 2,2$ & 5 & $218,5 \pm 0,1$ & 1 & $156,2 \pm 0,3$ & 1 \\
\hline \multirow[t]{3}{*}{$\begin{array}{c}\text { 'Čačanska } \\
\text { lepotica' }\end{array}$} & Nyers & $8,3 \pm 0,6$ & 6 & $3,34 \pm 0,1$ & 1 & $0,06 \pm 0,001$ & 1 \\
\hline & Lekvár & n.a & - & n.a & - & n.a & - \\
\hline & Aszalvány & n.a & - & $263,1 \pm 0,5$ & 1 & $216,1 \pm 0,4$ & 1 \\
\hline \multirow[t]{3}{*}{ 'Toptaste' } & Nyers & $75,5 \pm 2,4$ & 3 & $38,6 \pm 0,1$ & 1 & $31,4 \pm 0,3$ & 1 \\
\hline & Lekvár & n.a & - & $21,6 \pm 0,1$ & 1 & $3,45 \pm 0,1$ & 1 \\
\hline & Aszalvány & $25,7 \pm 2,6$ & 5 & $143,5 \pm 0,1$ & 1 & $100,09 \pm 0,1$ & 1 \\
\hline \multirow[t]{3}{*}{ 'Jojo' } & Nyers & $39,2 \pm 2,6$ & 6 & $40,1 \pm 3,9$ & 8 & $21,9 \pm 0,1$ & 1 \\
\hline & Lekvár & n.a & - & $24,26 \pm 0,1$ & 1 & $13,9 \pm 0,1$ & 1 \\
\hline & Aszalvány & $54,6 \pm 3,0$ & 5 & $296,2 \pm 0,1$ & 1 & $129,4 \pm 0,1$ & 1 \\
\hline \multirow[t]{3}{*}{ 'Topper' } & Nyers & $13,5 \pm 0,9$ & 6 & $3,3 \pm 0,1$ & 1 & n.a & - \\
\hline & Lekvár & n.a & - & n.a & - & n.a & - \\
\hline & Aszalvány & $63,56 \pm 7,4$ & 7 & $205,8 \pm 0,2$ & 1 & $47,8 \pm 0,3$ & 1 \\
\hline
\end{tabular}

n.a - nincs adat

\section{Következtetések és javaslatok}

Tarján - Lindner vizsgálatai alapján a friss, nyersszilva savtartalma közül $1,32 \mathrm{~g} / 100 \mathrm{~g}$ almasavat; $0,26 \mathrm{~g} / 100 \mathrm{~g}$ borkősavat; $0,16 \mathrm{~g} / 100 \mathrm{~g}$ borostyánkősavat és $0,11 \mathrm{~g} / 100 \mathrm{~g}$ citromsavat tartalmaz [8]. De fajtákra vonatkozólag nem mértek savtartalmat sem a friss gyümölcsnél, sem a belölük készült termékekben. Igaz, Tóth [10] vizsgálta a szilva aszalványok különbségeit a fajtákra nézve, de csak érzékszervi vizsgálatokkal, cukor és sav összetevőkre vonatkozólag nem. Mi méréseink során a savtartalom szempontjából az almasavnál kismértékü növekedést tapasztaltunk a lekvárrá főzés során. Az aszalványkészítésnél 4-8 szoros volt a növekedést. Ez azt jelenti, hogy a hő közléssel, ahelyett hogy elbomlottak volna a savak, inkább koncentrálódott az. A borostyánkősav esetében viszont a lekvárnál csökkenést, míg az aszalvánnyá alakulás során növekedést tapasztaltunk, ez azzal indokolható, hogy a magas hőfokon történő fözés során elbomlott a borostyánkősav egy része, míg az alacsonyabb $\left(40-50^{\circ} \mathrm{C}\right)$ höfokon nem bomlott le a borostyánkősav, viszont a vízvesztéssel koncentrálódott az, így relatív növekedést tapasztaltunk ennél az összetevőnél.

A cukortartalom esetén, mind a glükóz, mind a fruktóz összetevőnél az aszalvánnyá alakulás során növekedést tapasztaltunk, ami a vízvesztés következtében kialakuló cukorösszetevő koncentrálódással indokolható. A szacharóznál viszont egyes fajtáknál növekedést, más fajtáknál csökkenést tapasztaltunk, itt újabb mérésekkel kellene ellenőrizni ezen értékek helyességét.

Bíró- Lindner [2] vizsgálatai alapján a szilva 4,1 g/100 g szacharózt; 3,7 g/100 g glükózt; és $1,6 \mathrm{~g} / 100 \mathrm{~g}$ fruktózt tartalmaz, fajtára vonatkozólag itt sincsenek adatok.

A cukrok kimagasló értéke a tápértékre, kalóriára is utal, így a 'Jojo' aszalványa (296,2+-0,1 mg) a legmagasabb glükóz tartalmú, így igen magas tápértékű. A glükózról vagy más néven szőlőcukorról tudni lehet, hogy a sejtek fö energiaforrása, így ha szellemi munkát végzünk az 
agynak fontos, illetve sportolás vagy fizikai megterhelés során az izmok energiaellátásában játszik fontos szerepet.

A következő magas értéket $(216,1+-0,4 \mathrm{mg} / \mathrm{g})$ a fruktóznál a 'Čačanska lepotica' fajtánál említhető. A fruktóz előnye, hogy az emberi szervezetben lassabban emeli a vércukorszintet, így ez a cukortartalom a legkedvezőbb fogyasztás szempontjából, hiszen kevesebb az energia bevitel, így a cukorbetegek is fogyaszthatják korlátozott mennyiségben. Fogyasztása tartós fizikai megterhelés esetén javasolható. A fruktózt az inzulintól függetlenül használja fel a szervezet, hatásra zsírdeponálás fokozódik a szervezetben. A 'Toptaste friss gyümölcse tartalmazza a legtöbb $(75,5 \pm 2,4 \mathrm{mg} / \mathrm{g})$ szacharózt, ami az emberi szervezetbe való ásványi anyagok beépülését segítik elö.

Mivel a cukor és a savtartalom önmagában még nem ad tájékoztatást a gyümölcs és a belölük készült termékek ízére, zamatára, ezért a cukor-savarányt is érdemes megvizsgálni. Ez az arány adja meg, hogy mennyire harmonikus a gyümölcs íz-világa, mennyire kellemes fogyasztása.

A beltartalmi értékek analitikai vizsgálatai mellett érdemes lenne organoleptikus vizsgálatokat is végezni, mind a lekvár, mind az aszalvány tekintetében, hogy vakkóstolás során melyik lenne a legízletesebb, melyikböl lenne érdemes lekvár, illetve melyik lenne alkalmas aszalványkésztésre.

\section{Köszönetnyilvánítás}

Köszönettel tartozunk a kutatás támogatásáért, amely az EFOP-3.6.2-16-2017-00012 „Funkcionális, egészséges és biztonságos élelmiszer termékpálya modell kidolgozása a szántóföldtől az asztalig elv alapján, tematikus kutatási hálózatban" pályázat keretében valósult meg. A projekt a Magyar Állam és az Európai Unió támogatásával, az Európai Szociális Alap társfinanszírozásával, a Széchenyi 2020 program keretében valósul meg.

\section{Irodalomjegyzék}

[1] Bíró Gy. - Lindner K. (1988) Tápanyagtáblázat. Medicina Kiadó. Bp. Cyt. Surányi D. A szilva táplálkozás-élettani jelentősége. In: Surányi D. (szerk) Szilva. Mezőgazda Kiadó.

[2] Bíró Gy. - Lindner K. (1999) Tápanyagtáblázat. Medicina Kiadó. Bp. In: Papp J. (szerk.) (2003) 1. Gyümölcstermesztési alapismeretek. Mezőgazda Kiadó.

[3] Fazekas-Harsányi (1977) Kajszifajták és -fajtajelöltek alkalmasságának vizsgálata a felhasználás szempontjából. Fajtakísérletezés- Fajtaminősítés. cyt. Harsányi J. A szilva feldolgozása In: Tóth E.-Surányi D. Szilva (1980) Mezőgazdasági Kiadó.

[4] Hámoriné (1974) A gyümölcs növekedése. In: Gyúró F. A gyümölcstermesztés alapjai. (1974) Mezőgazdasági Kiadó.

[5] Hieronymus Füszerkönyve (1551) cyt. Fási K. (2015) Gyógyító zöldségek és gyümölcsök. Zen Kiadó

[6] Papp J. (2003): A gyümölcsök táplálkozásbiológiai jelentösége: In: Papp J. (szerk.) (2003) 1. Gyümölcstermesztési alapismeretek. Mezőgazda Kiadó. 26-34. p.

[7] Simon G. (2008): Néhány hazánkban termesztett szilvafajta alkalmassági vizsgálatai aszalványkészítés szempontjából. In: Gonda I. (szerk.) Magyar szilvatermesztés-stagnálás vagy elörelépés? 64.-71.p

[8] Tarján- Lindner (1981): Tápanyagtáblázat. Medicina Kiadó. Bp. In: Papp J. (szerk.) 1. Gyümölcstermesztési alapismeretek. Mezőgazda Kiadó.

[9] Tóth E. (1957): Alalaktani összehasonlító vizsgálatok szilvafajtákon. Cyt. Harsányi J. A szilva feldolgozása In: Tóth E.-Surányi D. Szilva (1980) Mezőgazdasági Kiadó.

[10] Tóth E. (1960): cyt. Harsányi J- Surányi D. A szilvagyümölcs aszalása In: Surányi D (2006) Szilva. Mezőgazda Kiadó. 285-287p.

[11] Buchloh, G. Neubeller, J. (1969) cyt. Hámoriné. A gyümölcs növekedése. In: Gyúró F. A gyümölcstermesztés alapjai. (1974) Mezőgazdasági Kiadó. 